\title{
İslâm Öncesi Medine
}

\section{Mahmut KELPETİ*}

Öz: Bu makale, İslâm öncesi Medine şehrinin fizikî ve coğrafi durumu ile burada Yaşayan Yahudi ve Arap kabileler hakkında bilgiler vermeyi hedeflemektedir. Medine'de yerleşimin ne zaman başladığı ya da kimlerin öncelikle buraya yerleştiği konusunda kaynaklarda farklı rivayetler bulunmaktadır. Bununla birlikte Hz. Peygamber'in hicreti sırasında şehirde başta Kaynukâ', Nadîr ve Kurayza Yahudileri olmak üzere Evs ve Hazrec gibi Arap kabileleri yaşamaktadır.

Anahtar Kelimeler: Yesrib, Yahudi, Evs, Hazrec, Amâlika, Kaynukâ', Nadîr ve Kurayza, Hz. Musa, Hz. Muhammed, Medine

\section{Madina before Islam}

Abstract: The aim of this article is to provide information about the physical and the geographical condition of pre-Islamic Madina which includes material on the Jewish and the Arabian tribes that resided in the city. In historical resources there are various reports regarding the first settlers and data about the first time they established themselves in Madina, which at that time was called Yathrib. Furthermore, this study will also demonstrate the settlement of Madina during the time of Prophet Muhammad's hijrah to Madina. The study will attempt to give detailed information about the people that were known to have lived in the city of Madina at that time. These people were mostly part of tribes such as the Jewish tribes of Banū Qaynuqā', Banū Nadīr, and Banū Qurayza as well as the Arabian tribes such as Aws and Khazraj.

Keywords: Yathrib, Jews, Aws, Khazraj, 'Amāliqa, Qaynuqā', Nadīr and Qurayza, Prophet Moses, Prophet Muhammad, Madina

Tarihteki ilk İslâm devletinin başkenti olan Medine, Arap yarımadasının batısında, Hicaz bölgesinde yer almaktadır. Medine, Mekke'den sonra İslâm’n ikinci kutsal şehri kabul edilmektedir. Mekke’nin yaklaşık 450 km. kuzeydoğusunda ve Kızıldeniz’in yaklaşık 160 km. doğusunda yer alan Medine, ${ }^{1}$ kuzeye doğru meyilli geniş bir düzlükte kurulmuştur. ${ }^{2}$ Şehrin kuzey kısmında denizden yüksekliği yaklaşık 1.000 metreye ulaşan Uhud dağları, güneyinde aynı yükseklikteki 'Ayr dağları, doğusunda siyah volkanik lav akıntılarıyla kaplanan Vâkım harresi ${ }^{3}$ ve batı kısmında Vebere harresi ${ }^{4}$ yer almaktadır. ${ }^{5}$ Medine çevresinde çok

\footnotetext{
Yrd. Doç. Dr., Marmara Üniversitesi İlahiyat Fakültesi İslâm Tarihi Anabilim öğretim üyesi.

E-posta: mahmut.kelpetin@marmara.edu.tr

1 Watt, "al-Madina”, EI², V, 994; al-Rashıd, "Medina”, Encyclopedia of Archaeology, III, 459.

Buhl, "Medine", $\dot{I} A$, VII, 459.

3 Amâlika kabilesinden Vâkım’a nisbetle bu adın verildiği rivayet edilir. bk.Yâkût, $M u^{\prime}$ cem, II, 249.

4 Medine’nin batısında bulunur. bk. Yâkût, $M u$ 'cem, II, 250.

5 Burrû, Târîh, s. 184.
} 
yaygın olan ${ }^{6}$ harrelerin ${ }^{7}$ zamanla verimli topraklara dönüştügü ve ziraata uygun hale geldiği bilinmektedir. ${ }^{8}$

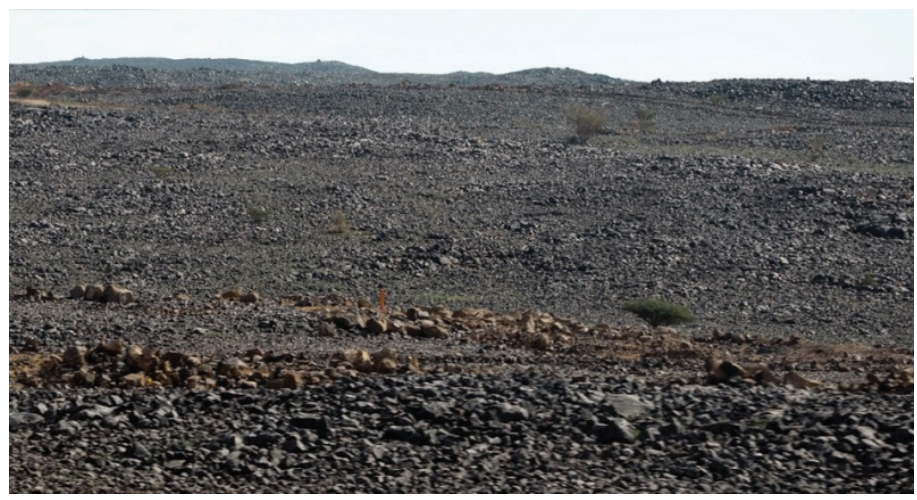

Resim 1: Medine'de harre örneği (๔ KURAMER)

Arap yarımadasında İslâm öncesi dâhil çeşitli volkanik patlamaları meydana geldiği bilinmektedir. Câhiliye şiirinde de buna işaret edilmektedir. ${ }^{9} \mathrm{~Hz}$. Ömer zamanında Harretü Leylâda ${ }^{10}$ ve Harretü’n-Nârda ${ }^{11}$ gerçekleşen patlamalar bunlardandır (19/640). Aynı şekilde Hz. Osman döneminde Medine yakınındaki bir takım volkanik dağlardan dumanlar yükselmiştir. Hicaz bölgesinde vuku bulduğu tespit edilen en son volkanik patlama 654/1256'da Medine’nin doğusunda meydana gelmiş ve birkaç hafta sürmüştü. ${ }^{12}$ "Hicaz ateşi” olarak tarihe geçen ${ }^{13}$ bu patlama sırasında sık sık yer sarsıntıları olduğu; kıyamet vaktinin geldiğini düşünen Medine halkının Allah’a dua etmeye başladığ $1{ }^{14}$ ve lav akıntılarının Medine’nin çok yakınlarına kadar ulaştığı rivayet edilmektedir. ${ }^{15}$

6 Geniş bilgi için bk. Yâkût, Mu'cem, II, 245-250.

7 Arapça'da ateşte yanmış gibi görünen, siyah bazalt kütleleri veya parçaları ile örtülü düzlük ve tepeciklerden meydana gelen volkanik alanlara harre (sıcak, kızgın) denilmektedir; lâbe de (lâva, lav) harre ile eş anlamlıdır. Özellikle Hicâz ve Yemen bölgesinde yaygındır (Burrû, Târîh, s. 28.) Yanardağların püskürmesi sırasında dışarı çıkan lavların soğuyarak katılaşması sonucunda meydana gelmektedir. Harre alanları, uzun zaman geçtikten sonra ortaya çıkmaktadır. Patlama sürecinde dağların tepelerinden kopan parçacıklar uzun mesafeler boyunca akıp aşağı kısımlarda birikmeye başlar. Daha sonra bu kısımlar herhangi bir harekete mâruz kalmazsa zamanla çöle dönüşmeye başlar (bk. Küçükaşçı, "Harre", DİA, XVI, 244; Yâkût, Mu'cem, III, 356).

8 Burrû, Târîh, s. 184.

9 Geniş bilgi için bk. Cevâd Ali, el-Mufassal, I, 147.

10 Taberî, Târîh, IV, 102; İbnü'l-Cevzî, el-Muntazam, IV, 281; İbnü’l-Esîr, el-Kâmil, II, 382. Yeri tam olarak belli değildir. Farklı rivayetler için bk. Yâkût, $M u^{\prime}$ 'cem, II, 247-248.

11 İbnü'l-Kelbî, Neseb, II, 728-729; İbn Şebbe, Târîhu'l-Medîneti'l-münevvere, II, 753; Belâzürî, Ensâb, X, 313. Yeri tam olarak belli değildir. Farklı rivayetler için bk. Yâkût, Mu'cem, II, 248-249; V, 18.

12 Cevâd Ali, el-Mufassal, I, 147; Tevfîk Burrû, Târîh, s. 29.

13 İbn Kesîr, el-Bidâye ve’n-nihâye, XVII, 339.

14 Diyârbekrî, Târîh, II, 372.

15 Cevâd Ali, el-Mufassal, I, 147; Buhl, "Medine”, IA, VII, 467. 


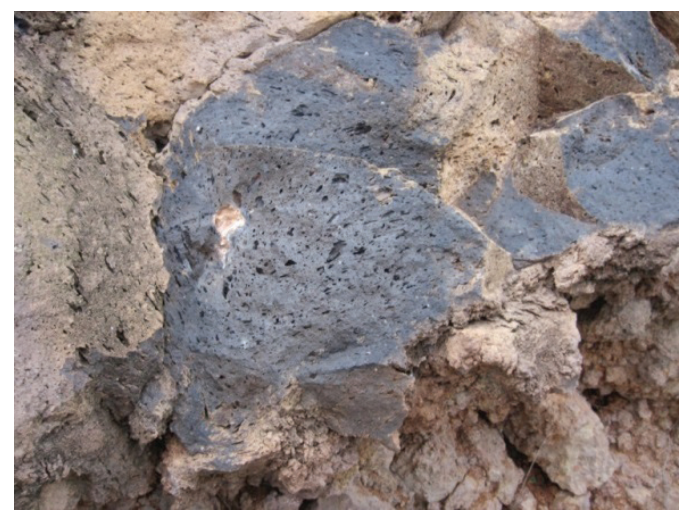

Resim 2: Medine’de bazalt taşı örneği (@Daniel Ventura)

Lav akıntılarının soğuması sonucunda oluşan ve dağınık taşlıklardan meydana gelen harrelerde yaşam şartları bazı zorluklar ihtiva etmektedir. Bununla birlikte eski dönemden itibaren pek çok kimsenin buralarda yaşamaya devam ettiği bilinmektedir. Bu bazalt lav akıntılarının altında zengin su rezervlerinin bulunduğu söylenir. Nitekim günümüzde Medine'deki zengin su kaynaklarının çoğunun harre bölgelerinde yer alması da bunu teyit etmektedir. Yine Benî Kurayza ${ }^{16}$ ve Benî Nadîr Yahudileri ile Evs'e mensup bazı kabilelerin Medine yakınlarındaki Harretü Vâkım'da oturması bunu desteklemektedir. ${ }^{17}$

Medine, zengin su kaynaklarının yanında fazla yağış alan bir bölgeydi. Şiddetli yağı̣slardan sonra zaman zaman sel baskınlarının yaşandığı ve el-Münahảnın ortasının sular altında kaldığı ve göle dönüştügü; bu durumun şehrin güneyinde kalan binalar için büyük tehdit oluşturduğu bilinmekteydi. Nitekim Hz. Osman döneminde, şehri ve Mescid-i Nebevî̀yi Mehzûr vadisinden gelen sel sularının neden olacağı baskınlardan koruyabilmek için bir sed yapılmıştır. ${ }^{18}$ 116/734 ve 140/757-758 yıllarında da şehirde ciddi sel baskınlarının yaşandı ğı rivayet edilmektedir. ${ }^{19}$ Nitekim Abbasî Halifesi Mansûr döneminde 156/763 yılında yağan şiddetli yağmurdan sonra Medine vadileri suyla dolmuş; bu durum şehri ve Mescid-i Nebevî̀yi tehdit eder hale gelmişti. Bunu önleyebilmek için kanallar açılmış ve suyun farklı yerlere dağılması sağlanmıştı. ${ }^{20}$ Diğer yandan şehirde suların bolluğuna rağmen bunların önemli bir kısmının tuzlu ve içilemez olduğu; içme sularının daha ziyade güneyde bulunan tatlı su kaynaklarından sağlandığı ve bunun için su kemerleri inşa edildiği söylenir. ${ }^{21}$

\footnotetext{
16 Semhûdî, Vefâ, IV, 58.

17 Küçükaşçı, “Harre”, DİA, XVI, 244.

18 İbn Şebbe, Târîh, I, 169; Belâzürî, Fütûh, s. 20; Yâkût, Mu'cem, V, 234.

19 Semhûdî, Vefâ, III, 212; Watt, "al-Madīna", EI², V, 994; Bozkurt-Küçükaşc1, "Medine”, DİA, XXVIII, 305.

20 İbn Şebbe, Târîh, I, 169.

21 Watt, “al-Madīna”, $E I^{2}, \mathrm{~V}, 994$.
} 
Medine'deki toprağın yapısına gelince bunun tuzlu bir toprak çeşidi olup kum, kalker ve kilden meydana geldiği söylenmektedir. Genel olarak topraklarının verimli olduğu bilinen Medine’nin doğal halinin "Ekin bitmez bir vadi” 22 olarak tavsif edilen Mekke'ye kıyasla oldukça farklı olduğu; özellikle güney bölgesinde daha verimli ve münbit arazilerin yer aldığ 1 bilinmektedir. ${ }^{23} \mathrm{Bu}$ nedenle Medine, havası ve tarıma elverişli arazileri, topraklarında yetişen mahsulün kalitesi sayesinde Arap yarımadasındaki en önemli ziraat merkezlerinden biri kabul edilmektedir. ${ }^{24}$ Özellikle hurma yetiştiriciliğinde çok önemli bir merkezdir. Hz. Peygamber'in risâletinden önce şehirde "hâit" olarak adlandırılan çok sayıda hurma bahçesi bulunuyordu. Aynı zamanda hububat da yetiştirilmekteydi. Daha sonraki dönemlerde ise portakal, limon, nar, muz, şeftali, kayısı, incir ve üzüm de yetiştirilmiştir. Kurak bir iklime sahip olan Medine’de kış mevsimi, serin ve genellikle yağışlı geçerken yazları sıcak ve çoğunlukla nem oranı düşük olarak seyreder. ${ }^{25}$ Yaz aylarında ortalama sıcaklık değeri $30^{\circ}$ ila $45^{\circ}$; kış aylarında $10^{\circ}$ ila $25^{\circ}$ arasındadır. Nem oranı ise oldukça düşük olup en düşük \%22, en yüksek \%35’e ulaşmaktadır. Yaz aylarında bu oran \%14'e kadar gerilemektedir. Bununla birlikte şehirde güneybatı yönünden esen rüzgarlar, havanın sıcaklığının yükselmesine neden olur. ${ }^{26}$ Medine’de önceki dönemlerde sıcaklığın daha mutedil olduğu ancak daha sonrasında arttığından bahsedilmektedir. Mekke’ye göre daha serin olan havasından dolayı şehre alışık olmayan ve dışarıdan gelenlerin Medine’de rahatsızlandığı ve hummaya yakalandığı bilinmektedir. ${ }^{27}$ Nitekim Mekke'den hicret eden bazı sahâbîler, ilk zamanlarda rahatsızlanmışlardır. ${ }^{28}$

Tablo 1. Medine İklim Bilgileri ${ }^{29}$

Aylar
En Yüksek ${ }^{\circ} \mathrm{C}$
Ort. En Yüksek ${ }^{\circ} \mathrm{C}$
Günlük Ortalama ${ }^{\circ} \mathrm{C}$
Ortalama En Düşük ${ }^{\circ} \mathrm{C}$
En Düşük ${ }^{\circ} \mathrm{C}$
Yağış mm
Ort. Çökelme gün
\% Nem

\begin{tabular}{|c|c|c|c|c|c|c|c|c|c|c|c|c|}
\hline 䒕 & $\begin{array}{l}\overrightarrow{\tilde{E}} \\
\vec{B} \\
\text { B. }\end{array}$ & $\stackrel{\bar{\Xi}}{\Sigma}$ & $\begin{array}{l}\text { 总 } \\
\text { 总 }\end{array}$ & 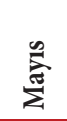 & 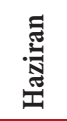 & 吉 & $\frac{\mathscr{8}}{0}$ & 章 & 章 & 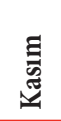 & 荥 & 当 \\
\hline 0 & 35.5 & 40.0 & 41.4 & 46.0 & 47.0 & 47.5 & 46.5 & 46.4 & 41.5 & 6.0 & 32.2 & \\
\hline & 26.1 & 30.2 & 33.9 & 9 & 41.7 & 39.3 & 2.2 & 41.0 & 36.4 & 29.7 & 5.0 & 34 \\
\hline & 19.9 & 23.8 & 27.6 & & 35.8 & 36.0 & 5.9 & 34.4 & 29.4 & 23.4 & 9.0 & 7.9 \\
\hline 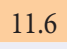 & 13.3) & 17.4 & 20.8 & & 27.9 & 28.4 & 28.7 & 7.1) & 21.9 & 17.2 & 12.9) & 1.0 \\
\hline 1.0 & 50 & 7.0 & 115 & 14.0 & 21.7 & 22.0 & 23.0 & 18.2 & 11.6 & 9.0 & 3.0 & 1 \\
\hline 8. & 1.2 & 8.3 & 11.9 & 4.6 & 0.4 & 0.2 & 0. & 0.1 & 1.1 & 9.2 & .8 & 9.1 \\
\hline 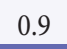 & & 1.2 & 2.5 & 1.1 & 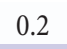 & 0.1 & 0.1 & - & 0.6 & 2.1 & 1.1 & 10.9 \\
\hline & 34 & 28 & 26 & 17 & 13 & 16 & 17 & 17 & 21 & 36 & 40 & 25.3 \\
\hline
\end{tabular}

22 İbrahim 14/37.

23 Cevâd Ali, el-Mufassal, VII, 132.

24 Mehrân, Dirâsât, s. 383.

25 Gadbân, Medîne, s. 33.

26 ftp://ftp.atdd.noaa.gov/pub/GCOS/WMO-Normals/RA-II/SD/40430.TXT (erişim tarihi: 05.06.2017).

27 Buhl, "Medine", IA, VII, 460.

28 İbn Hişâm, es-Sîre, I, 588.

29 Apaydın, "Siyer Coğrafyası’nın İklimi, Bitki Örtüsü ve Hayvanları", s. 29. 
Medine’nin bilinen en eski adının Yesrib olduğu rivayet edilir. ${ }^{30}$ Şehrin isminin buraya ilk yerleşen Yesrib b. Kâniye (Kâ'id) ${ }^{31}$ b. Mehlil (Mehlâil)'in adından geldiği kaydedilmektedir. ${ }^{32}$ Yesrib'le ilgili en eski bilgilere, son Babil kralı Nabonidus'un (M.Ö. 556539) Harran'da 1956 yılında ortaya çıkarılan bir yazıtında rastlanmaktadır. Nabonidus'un Arabistan’ın Suriye ve Güney Arabistan arasındaki ticaret yoluna hâkim olmak ve Araplar’1 Bâbil'in diğer bölgeleriyle uyumlu hale getirmek için Hicâz seferine çıktığı; Yesrib, Hayber ve Teymâyı kontrol altına aldığı anlaşılmaktadır. ${ }^{33}$ Diğer yandan Batlamyus ve Bizanslı coğrafya yazarı Stephanus'da "Iathrippa” (Yesrippa), Ma in kitâbelerinde "Ythrb” olarak geçmektedir. 34 “" kelimesinden türemiş olan Yesrib kelimesi, ${ }^{35}$ sözlükte "kınamak, azarlamak, başa kakmak ve kötülemek” gibi anlamlara gelmektedir. ${ }^{36}$ Aramî dilinde şehir anlamına gelen "medinta” sözcüğünün karşıllğ olan "Medine” kelimesi, ${ }^{37}$ önceleri "mahkeme yeri" ya da "kasaba" anlamında kullanılmaktaydı. Kur'an'da on yerde 38 geçen "Medine" kelimesi, genelde "şehir" manasında kullanılır. Yine bu kelimenin çoğulu olan "medâ' in" kelimesi üç yerde geçer. ${ }^{39}$ Dört yerde ${ }^{40}$ ise Allah Resûlü’nün hicret ettiği şehrin özel adı olarak zikredilmiştir. ${ }^{41}$ "Medine" şehir adı olarak sadece Ahzâb sûresinde geçmektedir. ${ }^{42}$ Benzer şekilde Medine anayasasında "Yesrib" adı ${ }^{43}$ ile birlikte "Medine" adına da yer verilmiştir. 44 "Medine" ismi önceleri, kuzeyde ilk yerleşmenin gerçekleştiği tahmin

30 Medine İslâm kaynaklarında et-Taybe, et-Tâbe, et-Tayyibe, el-Miskîne, el- 'Azrâ, el-Câbire (Cebâr), el-Mecbûre (Mahbûre), el-Muhabbebe, el-Mahbûbe, Yended ve Yesrib olarak anılır (bk. İbn Şebbe, Târîh, I, 161-162.

31 İbn Haldûn, el-'̇́ber, II, 342.

32 Yâkût, Mu 'cem, V, 430; Makrîzî, İmtâ' u’l-esmâ', XIV, 365; Cevâd Ali, el-Mufassal, VII, 128.

33 Cevâd Ali, el-Mufassal, II, 265-269; Mehrân, Dirâsat, s. 384.

34 Yesrib, Ma in topluluklarından bazılarının ikamet ettiği yerler arasında zikredilir. Nitekim neseb âlimleri de Yesribliler'in kökenlerini Yemen’e dayandırmaktadırlar (bk. Cevâd Ali, el-Mufassal, VII, 128).

35 “" kelimesinden geldiği de söylenir. Geniş bilgi için bk. el-Bekrî, Mu'cem, III, 900; IV, 1389; Yâkût, Mu'cem, V, 430.

36 Yâkût, $M u^{\prime}$ cem, V, 430.

37 Cevâd Ali, el-Mufassal, VII, 130; Mehrân, Dirâsat, s. 387.

38 el-Árâf 7/123; Yusuf 12/30; el-Hicr 15/67; el-Kehf 18/19, 82; en-Neml 27/48; el-Kasas 28/15, 18, 20 ; Yâsîn 36/20.

39 el-Árâf 7/111; eş-Şuarâ 26/36, 53.

40 "Çevrenizdeki bedevîlerden birtakım münafiklar vardır. Medine halkından da münafiklıta direnenler var ki sen onları bilmezsin..." (et-Tevbe 9/101); "Medine halkı ve onların çevresinde bulunan bedevîlere, Allahìn Resûlünden geri kalmak, kendi canların onun canından üstün tutmak yaraşmaz...” (et-Tevbe 9/120); “And olsun, eğer münafiklar, kalplerinde bir hastalık bulunanlar ve Medine’de kötü haberler yayıp ortalı̆̆ı karıştıranlar (tuttukları yoldan) vazgeçmezlerse, elbette seni onlarm üzerine gitmeye teşvik edeceğiz...” (el-Ahzâb 33/60); “Onlar, And olsun, Medine’ye dönersek, üstün olan, zayıf olanı oradan mutlaka çıkaracaktır' diyorlardı...” (el-Münâfikûn 63/8).

41 Watt, "al-Madina”, EI², V, 994; Bozkurt-Küçükaşcı, "Medine”, DİA, XXVIII, 305-306.

42 O sıra münafıklardan bir grup "Ey Yesrib (Medine) halkı! Sizin burada durmak imkânınız yok. Haydi geri dönün” demişti. Onlardan bir başka grup da "Evlerimiz açık (korumasız)" diyerek Peygamberden izin istiyorlardı. Oysa evleri açık (korumasız) değildi. Onlar sadece kaçmak istiyorlardı” (el-Ahzâb 33/13).

43 İbn Hişâm, es-Sîre, I, 501.

44 Câhiliye döneminde doğan Medineli şair Kays b. Hatîm’in şiirlerinde Yesrib kelimesini kullandı̆̆ı; diğger yandan Hz. Peygamber'in meşhur üç şairinden olan Hassân b. Sâbit ve Ka 'b b. Mâlik’in hem Medine hem Yesrib kelimesini kullandığı dikkati çeker (bk. İbn İshâk, es-Sîre, s. 84; Vâkıdî, el-Megâzî, I, 375; İbn Hişâm, es-Sîre, II, 144, 287). 
edilen Curf ile Kanât vadileri arasında kalan yeri ${ }^{45}$ ifade etmesine rağmen daha sonra şehrin tamamı için kullanılmıştır. ${ }^{46}$

Hz. Peygamber'in Mekke'den Medine'ye hicret etmesinden sonra "kınamak, azarlamak" gibi olumsuz anlamlar taşıyan "Yesrib" ismi yerine, 47 "hoş" ve "güzel” manalarına gelen "Tâbe” veya "Taybe” gibi adlar verdiği, Yesrib denmesini istiğfarı gerektiren bir günah olarak nitelediği rivayet edilmektedir. ${ }^{48}$ Ayrıca Kur'an'da zikri geçen "ed-Dâr" ${ }^{49}$ kelimesinden hareketle ${ }^{50}$ Medine'ye hicret yurdu manasında "Dârü'l-hicre”, imanın ve İslâmiyet'in merkezi anlamında "Dârü'l-îmân”, Allah Resûlü’nün sünnetinin yaşandığı yer olarak "Dârü’s-sünne”, orada yaşayanlara nispetle "Dârü'l-ebrâr", ${ }^{51} \mathrm{~Hz}$. Peygamber'e nisbetle "Medînetü'r-Resûl" 52 (Medînetün-Nebî) ve "nurlu şehir” manasında "el-Medînetü’l-münevvere” gibi farklı isimler verilmiştir. ${ }^{53}$ Emevîler döneminde halkın yönetime destek vermemesinden dolayı şehre "kirli" ve "kötü" anlamında "el-habîse" de demişlerdir. ${ }^{54}$

Medine’ye ilk yerleşimin ne zaman olduğu hususunda kaynaklarda kesin bir bilgi yoktur. Bununla birlikte şehrin verimli arazilere sahip olmass ${ }^{55}$ ve Yemen'i kuzey bölgelerine bağlayan ticaret yolu üzerinde bulunması nedeniyle yerleşimin eski dönemlere kadar uzanması mümkündür. Medine’ye yerleşen topluluklar arasında Amâlika, ${ }^{56}$ Yahudiler, Evs ve Hazrec kabileleri sayılmaktadır. Ancak bunlardan hangilerinin daha önce şehre gelip yerleştiği bilinmemektedir. Konu hakkında kaynaklarda ileri sürülen görüşler özetle şöyledir: 1) Yesrib’e ilk olarak Ubeyl kabilesinin mensupları yerleşti. Daha sonra Amâlikalılar buraya geldi ve onları Yesrib’ten çıkardı. ${ }^{57}$ 2) Amâlika kabilesinden Amelâk b. Erfahşed b. Sâm b. Nûh ${ }^{58}$ ve

45 Yâkût, $M u^{\prime}$ cem, V, 430; Semhûdî, Vefâ, I, 13.

46 Bozkurt-Küçükașc1, "Medine”, DİA, XXVIII, 305.

47 Yesrib’in diğer isimleri için bk. Semhûdî, Vefâ, I, 13-32.

48 Ahmed b. Hanbel, el-Müsned, XXX, 483.

49 “Onlardan (muhacirlerden) önce o yurda (Medine’ye) yerleşmiş ve imanı da gönüllerine yerleştirmiş olanlar, hicret edenleri severler" (bk. el-Haşr 59/9).

50 Yazır, Hak Dini Kurân Dili, VII, 4842.

51 Semhûdî, Vefâ, I, 18.

52 Halîl b. Ahmed el-Ferâhidî, Kitâbü'l- 'Ayn, VII, 461, VIII, 153.

53 Bozkurt-Küçükaşcı, "Medine”, DİA, XXVIII, 305.

54 Belâzürî, Ensâb, II, 49; Watt, “al-Madina”, $E I^{2}$, V, 994.

55 Watt, “al-Madina”, $E I^{2}, \mathrm{~V}, 994$.

56 Amâlika kabilesi, Tevrat’a göre dünyanın en eski milletidir (Sayılar, 24/20) ve anayurtları Akabe körfezi ile Lût gölü arasında yer alan Edom bölgesidir. İslâmî kaynaklarda kavim hakkındaki bilgiler ihtilaflıdır ve rivayetlerin önemli ölçüde Tevrat’tan geçtiği kabul edilmektedir. Tevrat’a göre kabilenin atası Hz. İshak’ın torunu, Elifaz’ın câriyesi ve Timna'dan doğan oğlu Amalek'tir (Tekvîn, 36/12; I. Tarihler, 1/36). İslâmî kaynaklarda ise durum biraz daha farklıdır. Kavmin atası Amlâk (İmlâk, Umlûk) b. Lâvez (Lâvuz, Levd, Lud) bazan Hz. Nûh'un oğlu Sâm’a (İbn Sa 'd, et-Tabakât, I, 26; Taberî, Târîh, I, 207), bazan da diğer oğlu Hâm’a bağlanmaktadır (Taberî, Târîh, I, 207). Bu farklılığın sebebi Hz. İshak'in torununu Elifaz ile Sâm’ın oğlu ve Hâm’ın da torununun adı olan Lâvez’in aralarındaki ses benzerliğinden dolayı (lfz, lvž,) birbirine karıștırılmış olmalıdır (bk. Erdem, “Amâlika”, DİA, II, 556-557).

57 İbn Sa 'd, et-Tabakât, I, 28; İbn Habîb, el-Muhabber, s. 385; Belâzürî, Ensâb, I, 6.

58 Yâkût, $M u^{\prime}$ cem, V, 84 . 
beraberindekiler ilk olarak Yesrib’e yerleșmiş ve buraları yurt edinmiștir. ${ }^{59}$ 3) Amâlika kabilesi mensupları Mekke, Tâif ve Yesribe yerleşti. ${ }^{60}$ Bir süre sonra kibirlenmeye ve zorbalık yapmaya başladıkları için Hz. Mûsâ, Erkam b. Ebü’l-Erkam’ın liderliğindeki Amâlika mensuplarına karşı bir ordu gönderdi. İsrailoğulları’ndan oluşan bu ordu, onları ağır bir hezimete uğrattı ${ }^{61}$ ve Erkam’ın oğlu dışındaki Amâlika mensuplarını öldürdü. Daha sonra askerler geriye döndüler ve Hz. Mûsẩnın vefat ettiğini öğrendiler. Bölge halkı ise askerlerin Hz. Mûsânın emrine aykırı davranıp Amâlikalılar’ın tamamını öldürmemelerine kızdı ve onları Filistin'den çıkardı. Bunun üzerine askerler Yesrib’e yerleştiler. ${ }^{62}$ İslâmî kaynaklarda yer alan bu rivayetin muhteva itibariyle bir benzeri Tevrat'ta da bulunmaktadır: Rivayete göre Hz. Mûsânın emri üzerine Medyenliler ile mücadele eden Benî İsrail ordusu, savaşta tüm erkekleri öldürmüş; kadın ve çocukları esir almış; hayvanları, eşyaları yağmalamış ve şehirleri ateşe vermişti. Daha sonra onlar, ganimet olarak aldıkları mallar ve esirlerle birlikte Mûsẩnın huzuruna çıkmışlardı. Ancak Mûsâ, kadınları öldürmeyip sağ bıraktıkları için onlara kızmış ve verilen emri yerine getirmelerini istemişti. ${ }^{63}$ 4) Hz. Mûsâ, İsrailoğulları’ndan bir grup ile birlikte Mekke'de ifa ettiği hac vazifesinden sonra Yesrib’e uğradı ve burasının Tevrat'ta geleceği müjdelenen son peygamberin yaşayacağ ${ }_{1}$ coğrafyaya uygun olduğunu bildirdi. Bunun üzerine İsrailoğulları’nın bir kısmı, bu şehirde kalmaya karar verdi. Daha sonra onlar Benî Kaynukâ' kabilesinin yaşadığı yere yerleşti. ${ }^{64}$ 5) Hz. Mûsâ ve Hz. Hârûn, Yahudilerden korktuğu için Medine’ye geldi. Bu sırada Hz. Mûsâ, hasta olan kardeşinin öleceğini anladı ve ondan kabre girmesini söyledi. Hz. Hârûn da ağabeyinin isteğini yerine getirdi ve Uhud'da bulunan kabre uzandı. Hz. Mûsâ da üzerine toprak atıp mezarı kapattı. ${ }^{65} 6$ ) Bazı tarihçiler eski zamanlarda Sa 'ul ve Fâlic ismi verilen kabilelerin Yesrib’te yaşadığını, Hz. Dâvûd'un onlarla mücadele ettiğini ve çok sayıda kimseyi esir aldığını ${ }^{66}$ daha sonra bu kimselerin yok olup gittiğini ve kabirlerinin/mezarlarının Curf’ta olduğunu söyler. ${ }^{67}$ 7) Babil kralı Buhtunnasr (Nebukadrezzar)'ın ${ }^{68}$ Kudüs'ü işgal edip (M.Ö. 587) Süleyman mabedini

59 İbn Sa 'd, et-Tabakât, I, 28; İbn Habîb, el-Muhabber, s. 385; Ebü’l-Ferec el-İsfahânî, el-Eğânî, III, 82, XXII, 343; Yâkût, Mu'cem, V, 84; İbn Haldûn, el-'İber, I, 444; Semhûdî, Vefâ, I, 125.

60 Amâlikalılar'ın önce Mekke’ye yerleştiği daha sonra Yesrib’e geldiği de rivayet edilir (bk. İbnu'l-Cevzî, el-Muntazam, I, 243). Diğer yandan kaynakların Amâlika kavminin yaşadığı yerlerle ilgili farklı rivayetlere yer verdiği unutulmamalıdır. Onların Umân, Hicâz, Suriye ve Mısır bölgelerinde yaşadıklarının söylenmesi buna en iyi örnektir. Karşılaştırma için bk. Taberî, Târîh, I, 203.

61 İbn Rüste, el-A'lâku'n-nefîse, s. 60-61.

62 Ebü’l-Ferec el-İsfahânî, el-Ĕ̆ânî, XXII, 343; el-Bekrî, el-Mesâlik, I, 413-414; Süheylî, er-Ravdü’l-ünüf, IV, 172.

63 Sayılar, 31/7-18. Değerlendirme için bk. Arslantaş, Hz. Muhammed Döneminde Yahudiler, s. 72.

64 Yâkût, Mu'cem, V, 84; Semhûdî, Vefâ, I, 128; Günaltay, İslâm Öncesi Arap Tarihi, s. 251. Ancak mübalağa ve efsane unsurlarıyla süslenen bu rivayet, tarihî hakikatlerle uyuşmamaktadır.

65 Semhûdî, Vefâ, I, 129.

66 Rivayette 100.000 bâkirenin esir alındığından ve Medineliler'in Allah Teâla’nın gönderdiği ve halka musallat olan kurtlar nedeniyle insanların yok olduğundan bahsedilir (geniş bilgi için bk. İbn Rüste, el-A lâku’n-nefîse, s. 59; Semhûdî, Vefâ, I, 126). Ancak mübalağa ve efsane unsurlarıyla süslenen bu rivayetin tarihî gerçeklerle çeliştiği ve mantık açısından da tutarsız olduğu anlaşılmaktadır.

67 İbn Rüste, el-A lâku’n-nefîse, s. 59-60.

68 Geniş bilgi için bk. Harman, "Buhtunnasr”, DİA, VI, 380-381. 
yıkmasından sonra Yahudilerin buradan çıkarıldıkları ${ }^{69}$ ve Arabistan yarımadasının Hicâz, Vâdi'l-kurâ, Hayber, Teymâ, Yesrib ve Eyle gibi çeşitli bölgelerine gittikleri rivayet edilmektedir. Bunlardan Yesrib’e gelenler başlangıçta şehrin kenar kısımlarına yerleşmişler, zamanla güçlenerek burada oturan Amâlika ve Cürhümlüler’i dışarı çlkarmışlar. Böylece şehrin hâkimiyetini ellerine geçirmişlerdir. ${ }^{70}$ 8) Milâttan sonra 70 yılında Titus kumandasındaki Roma askerleri Kudüs'ü ele geçirmişti. Bu sırada mâbed ve neredeyse bütün şehir yanmıștı. Bunun üzerine Yahudilerden bir grup şehirden ayrılmış ve Yesribe yerleşmişti. ${ }^{71}$ İmparator Hadrianus (117-138) zamanında ise Romalılar, Kudüs harabeleri üzerine yeni bir putperest şehir kurmak istediler. Buna tepki gösteren Yahudiler, Romalılar’a karşı ayaklandı. İsyanın bastırılmasından sonra (135) mâbedin yerine putperest tapınağı inşa edildi ve Yahudiler de buradan sürüldü. Bunun üzerine onların bir kısmı Yesrib’e gitti ${ }^{72}$ ve şehrin dışına yerleştiler. Daha sonra burada oturan Amâlika ve Cürhümlüler’i dışarı çlkardılar ve şehrin hâkimiyetini ellerine geçirdiler. ${ }^{73}$ Bununla birlikte bunlardan hangisinin şehre daha önce yerleştiği hususu belli değildir. Bu konuda müslüman tarihçilerin verdiği bilgilerin genel olarak bir varsayıma dayalı olduğu görülmektedir. Diğer yandan şehrin ilk sakinlerinin Araplar olduğu söylenebilir. Ancak bunların hangi kabileye mensup oldukları ya da nereden geldikleri hususundaki haberlerin mevsukiyeti tartışmalıdır. Bu hususun aydınlatılabilmesi için bazı yeni bilgilerin ortaya çıkmasını beklemek gerekir. ${ }^{74}$

Yahudilerin Yesrib’e gelişi ve yerleşmesiyle ilgili rivayetler incelendiğinde şu hususlar öne çıkmaktadır:

69 Rivayete göre Buhtunnasr'ın sürgününden sonra Kudüs'ten ayrilan Yahudilerin bir kısmı Suriye ve Yemen bölgeleri arasında Tevrat’ta geleceği müjdelenen peygamberin yaşayacağı yeri bulmak için yola çıkıp bunun için en uygun yerin Yesrib olduğuna kanaat getirerek buraya yerleştiler (bk. İbn Asâkir, Târîh, III, 416).

70 Belâzürî, Fütûh, s. 25; Taberî, Târîh, I, 539; İbnü’l-Verdî, Târîh, I, 84; Semhûdî, Vefâ, I, 128; Buhl, “Medine”, İA, VII, 460; Watt, "al-Madīna”, $E I^{2}$, V, 994; Bozkurt-Küçükaşc1, "Medine”, DİA, XXVIII, 306; Avc1, "Kaynukā'”, DİA, XXV, 88.

71 Yahudiler'in Kudüs'ten ayrılmasıyla ilgili bir başka rivayet ise şöyledir: Romalılar, Filistin bölgesini ele geçirdikten sonra Suriye valisi, Hârûnoğulları̉ndan biriyle evlenmek istedi. AncakYahudi hukuku, bu tür evliliklere izin vermediği için onlar bu teklife şiddetli tepki gösterdi. Daha sonra da ziyafet bahanesiyle çağırdıkları valiye suikast düzenlediler ve onu öldürdüler. Ardından da çölün içlerine doğru kaçtılar. Romalılar da Hicâz’a doğru kaçan Yahudileri takip ettiler, ancak yakalayamadılar. Çölde aç ve susuz kalan Roma askerleri, Suriye-Medine yolu üzerinde bulunan Semed’e geldiklerinde (Yâkût, Mu'cem, II, 84) Yahudilerden hurma istediler. Ancak onlar, bunu vermedikleri gibi askerlerin hepsini öldürdüler. Bu yer, daha sonra "Semedü’r-Rûm” olarak anıldı (Yâkût, Mu'cem, II, 84, V, 84; Semhûdî, Vefâ, I, 128). Bu olayın Yahudilerle Araplar arasında yaşandığını söyleyen Moshe Gil’e göre Hârûnoğulları'dan çöle doğru kaçan yaklaşı 80.000 kişi, bedevî İsmailîler'den (Araplar) su istedi. Bedevîler ise Yahudilere bol tuzlu yemek ile su ihtiyaçlarını gidermeleri için hava ile şişirilmiş kırbalar verdi. Araplar kırbalardan su içmek isteyen Yahudileri, içi hava dolu bu kırbaları onların ağızlarına dayamak suretiyle boğup öldürmek istediler. Gil, Talmud'daki "İşte amcazadelerinin onlara karşı muamelesi böyleydi” ifadesinin de bu olayla ilgili olduğunu söyler (bu bilgi için bk. Arslantaş, Hz. Muhammed Döneminde Yahudiler, s. 74).

72 Cevâd Ali, el-Mufassal, XII, 98; Gil, “The Origin of the Jews of Yathrib”, s. 209; Mehrân, Dirâsât, s. 401; Harman, "Kudüs", DİA, XXVI, 325; Güç, "Yahudilik”, DİA, XLIII, 209.

73 Belâzürî, Fütûh, s. 25; Taberî, Târîh, I, 539; İbnü’l-Verdî, Târîh, I, 84; Semhûdî, Vefâ, I, 128; Buhl, "Medine”, İA, VII, 460; Watt, "al-Madinna", $E I^{2}$, V, 994; Bozkurt-Küçükaşc1, "Medine”, DİA, XXVIII, 306; Avc1, "Kaynukā'”, DİA, XXV, 88.

74 Watt, "al-Madina”, $E I^{2}$, V, 994. 
a) Yahudilerin Hz. Mûsâ döneminde Yesrib’e gelmesiyle ilgili rivayetler, dinî ve tarihî metinler ile desteklenmediği gibi muhteva açısından da bazı şüpheler ihtiva etmektedir. Meselâ insanlığa örnek olarak gönderilen Hz. Mûsânın, vazifesinin dişına çıkıp suçlu-suçsuz ayrımı yapmaksızın herkesin öldürülmesini istemesi; buna rağmen askerlerin emre aykırı davranmaları ve Amâlika kralının oğlu dışındaki kimseleri öldürmeleri, daha sonrasında pişmanlık duymaları vb. hususlar tarihî hakikatlerle uyuşmadığı gibi nübüvvet açısından da izah edilmesi zordur. Ayrıca soykırım ya da katliamı çağrıştıran bu ifadeler, Kur’an'daki bazı âyetlerle ${ }^{75}$ de çelişmektedir.

b) Hz. Mûsânın hem İsrailoğulları ile beraber Medine'ye gelmesini hem de Yahudilerden korktuğu için Hz. Hârûn ile birlikte bu seyahati yaptığını söylemek de çelişkidir. Yine Hz. Mûsâ döneminde bazı Yahudi kabilelerin Yesrib’e yerleştikleri söylenmesine rağmen Hz. Peygamber zamanında Medine’de yaşayan diğer Yahudi kabilelerin ataları ile irtibatlarının kurulamaması bir diğer problemdir. Ayrıca Hz. Mûsânın ziyaret esnasında kardeşinin öleceğini anlaması, vefatından önce Uhud'da olduğu söylenen kabre sokması ve üstüne toprak atması da hakikatten oldukça uzaktır. Üstelik yaygın olan geleneğe göre Hz. Hârûn'un kabrinin Petrầnın batısındaki Cebel-i Hârûn denilen Hor dağında olduğu da unutulmamalıdır. ${ }^{76}$

c) İslâm kaynaklarda aynı konuya yer veren rivayetler arasındaki bu çelişki ya da farklılığın en önemli nedenlerinden biri de onların bu haberleri tahrif edilmiş Tevrat'tan almış olmalarıdır. Nitekim Medyen olayı hakkında Tevrat'ta geçen rivayetin muhteva itibariyle İslâm kaynaklarında da yer alması bunu teyid etmektedir. Hz. Dâvûd zamanında gerçekleştiği söylenen rivayetleri de bu çerçevede düşünmek gereklidir. Özellikle M.Ö. X. yüzyılda yaşadığı kabul edilen Hz. Dâvûd'un savaştıktan sonra 100.000 bakireyi esir alması, rivayetteki tahrifatı, aşırılık ve mübalağayı açıkça ortaya koymaktadır. Diğer yandan esir alınanların sayısı bu kadar çoksa savaşanların kaç kişi olduğunu tahmin edebilmek ve bunların küçük bir mekanda savaştığını söylemek de imkansızdır. Yine esir alındığı söylenenlerin cezaya çarptırıldığı ifade edilmesine rağmen işledikleri suçlardan hiç bahsedilmemesi de gariptir. Dolayısıyla rivayetlerdeki bu ifade ve tasvirlerin doğruluktan uzak ve hayalî unsurlar olduğu söylenebilir. 77

d) Yahudilerin Yesrib’e milattan önce yerleşmesiyle ilgili rivayetlerdeki bir diğer sorun, bu bilgileri teyit edecek tarihî kayıtların ya da vesikaların bulunmamasıdır. Yahudilerin

\footnotetext{
75 “Kavmim! Allah’n size yazdı̆̆ı kutsal toprağa girin. Sakın ardınıza dönmeyin. Yoksa ziyana uğrayanlar olursunuz. Dediler ki: 'Mûsâ! O (dediğin) topraklarda gayet güçlü, zorba bir millet var. Onlar oradan çıkmadıkça, biz oraya asla giremeyiz. Eğer oradan çıkarlarsa, biz de gireriz.' Korkanların içinden Allah’n kendilerine nimet verdiği iki adam şöyle demişti: 'Onların üzerine kapıdan girin. Oraya girdiniz mi artık siz kuşkusuz galiplersiniz. Eğer müminler iseniz, yalnızca Allahia tevekkül edin.' Dediler ki: 'Mûsâ! Onlar orada bulundukça, biz oraya asla girmeyeceğiz. Sen ve Rabbin gidin, onlarla savaşın. Biz burada oturacağız.' Mûsâ, 'Rabbim! Ben ancak kendime ve kardeşime söz geçirebilirim. Artık bizimle, o yoldan çıkmışların arasını ayır' dedi. Allah, 'O hâlde, orası onlara kırk yıl haram kılınmıştır. Bu süre içinde yeryüzünde şaşkın şaşkın dönüp dolaşacaklar. Artık böyle yoldan çıkmış kavme üzülme’ buyurdu” (el-Mâide 5/21-26).

76 Harman, "Hârûn”, DİA, XVI, 255.

77 Daha geniş bir değerlendirme için bk. Mehrân, Dirâsat, s. 389-398.
} 
Yesrib’e yerleşmelerinden önce Yemen ve Mısır gibi bölgelerdeki hayatları hakkında kaynaklarda çok miktarda bilgi olmasına rağmen Yesrib’teki faaliyetlerine hiç yer verilmemesi de makul değildir. Yine tarihî vesikalarda Babil kralı Nabonidus'un (M.Ö. 556-539) bu bölgeye düzenlediği seferlerden ya da Yahudilerden bahsedilmemesi de garipsenecek bir durumdur. Diğer yandan Nabatîler döneminde ortaya çıkarılan kitâbelerdeki bilgilerde Yahudilerin varlığının milattan sonraki ilk zamanlara işaret etmesi de dikkate alınması gereken önemli bir delildir. Son olarak Buhtunnasr'ın Kudus'ü işgalinden sonra Yahudilerin Keldâniler'den korktukları ve hayatta kalabilmek için önlerinde tek kurtuluş yolu olan Mısır'a gittikleri söylenebilir. ${ }^{78}$ Bununla birlikte içlerinden bir kısmının farklı yerlere seyahat etmesi de mümkündür. Ancak bu Müslüman tarih kaynaklarının da bahsettiği gibi onların Yesrib’e toplu yerleşme tezini doğrulamamaktadır. Bütün bu tartışmalardan sonra Yahudilerin Yesrib’e yerleşmesinin Titus’un 70 yllında Kudüs'ü işgali sonrasındaki bir zamana denk geldiği söylenebilir. Ayrıca Hz. Peygamber zamanında yaşayan Yahudi kabilelerinin soy kütükleri de bunu teyit etmektedir.

Hz. Peygamber'in hicreti sırasında Medine'de yirmiden fazla Yahudi kabilesinin yaşadığg 1 rivayet edilmektedir. ${ }^{79}$ Benî Kurayza, Nadîr ve Kaynukâc bunların en meşhurlarıydı. ${ }^{80}$ Şehirde yaşayan bu kabilelerin bir kısmının kökeni Yahudi olmasına rağmen Arap soyu ile de anılmaktadır. ${ }^{81}$ Bu kabilelerin soyları konusunda kaynaklarda iki farklı görüş vardır: Tartışma özellikle iki kardeş kabile olan Benî Nadîr ve Kurayza üzerinden yapılmaktadır. Birinci görüşe göre Yesrib’e yerleşen Yahudi kabilelerinin soyları, İsrailoğulları̉na dayanır. Bunlardan Benî Nadîr ve Kurayza’nın soyu Hz. Hârûn’a, ${ }^{82}$ Benî Kaynukâ' kabilesinin kökeni ise Hz. Yusuf'a dayanmaktadır. ${ }^{83}$ Konu hakkında öne sürülen bazı iddialar şöyledir: 1) Medine’de yaşayan Yahudiler için Kur’an’da "Ey İsrailoğulları!" 84 hitabının kullanılması. 2) Hz. Peygamber'in Kurayza kabilesini kuşattığında onlara "maymunların kardeşleri” diyerek ${ }^{85} \mathrm{Al}$ lah’n geçmişte verdiği cezayı ${ }^{86}$ hatırlatması. 3) Hz. Peygamber, Hayber fethi sonrası evlendiği Safiyye bint Huyey b. Ahtab’n soyuyla ilgili Hz. Âişe ile arasında yaşadığı kıskançlık sonrası üzüldüğünü görünce ona "Babam Hârûn, amcam Mûsâ, eşim de Hz. Muhammed!

78 Bunun üzerine büyük küçük bütün halk ordu komutanlarıyla birlikte Mısır’a kaçtı. Çünkü Keldânîler'den korkuyorlardı (II. Krallar, 25/26).

79 Semhûdî, Vefâ, I, 132.

80 Medine'de bu sırada bulûğ çağına ermiş iki binden fazla Yahudinin olduğu söylenir (Mehrân, Dirâsat, s. 402; Burrû, Târîh, s. 186).

81 Watt, "al-Madina", $E I^{2}, \mathrm{~V}, 995$.

82 Bu soydan geldikleri için el-Kâhinân olarak isimlendirilmişlerdir (bk. Vâkıdî, el-Megâzî, II, 441; İbn Sa 'd, et-Tabakât, VII, 420; İbn Kuteybe, el-Ma' ârif, s. 458).

83 İbn Hibbân, es-Sikât, III, 228.

84 el-Bakara 2/40, 47, 122.

85 İbn Hişâm, es-Sîre, II, 234; Taberî, Târîh, II, 582.

86 "Şüphesiz siz, içinizden Cumartesi yasağın çiğneyenleri bilirsiniz. Biz onlara, 'Aşağllık maymunlar olun' demiştik” (elBakara 2/65); "Yasaklandikları şeylerden vazgeçmeye yanașmayınca da onlara 'aşağıllk maymunlar olun' dedik" (elA'râf 7/166). 
Benden nasıl hayırlı olursun deseydin ya!" diyerek teskin etmesi. ${ }^{87} 4$ ) Bazı Yahudilerin isimleri Arapça olmasına rağmen onların baba ya da önceki kuşaktaki temsilcilerinin isimlerinin İbranice olması. 5) Neseb âlimlerinin Medine’de yaşayan Arap kabileleri arasında Yahudi kabilelerine yer vermemesi. ${ }^{88} 6$ ) Yahudilerin bedevî Araplar gibi bir yerden diğerine göç etmemesi ve yerleşik hayatı benimsemeleri. ${ }^{89} 7$ ) Kuzey Arabistan ve bu arada Yesrib’teki Yahudilerin düşünce, ahlâk, gelenek ve göreneklerinde Araplar'dan ziyâde Yahudilere yakın tutum sergilemesi. ${ }^{90}$ Yahudilerin köken olarak Araplar'dan geldiğini savunanlara göre Benî Nadîr ve Kurayza, Arap asıllı olup Cüzâm kabilesine mensuptur. Onlar Amâlika’nın bağlı olduğu dini ve putlara ibadeti terk edip Hz. Mûsânın dinine girmişlerdir. Daha sonra da Suriye’den göç edip Yesrib’e yerleşmişlerdir. ${ }^{91}$ Bunların delilleri ise şu şekildedir: 1) Yahudiler İbranîce isimlerden daha ziyade Arapça adlar kullanmışlardır. ${ }^{92}$ 2) Avrupalı göçmenler, Amerika'da birlikte yaşadıkları ve alt kültüre mensup Kızılderililer'in kültürünü benimsemediler. Yahudiler ise sosyo-kültürel açıdan kendilerinden alt seviye olan Arap kültürüne uyum sağlamışlardir. ${ }^{93}$

Yesrib’e yerleşen Yahudilerin soyu konusunda mevcut rivayetler dikkate alındığında Arap yarımadasındaki Yahudilerin tamamının soyunun İsrailoğulları’na dayandı̆̆ı ya da Arap olduğu söylenemez. Dolayısıyla birbirinden farklı bu iki görüşü tevil edebilmek ve birini diğerine tercih edebilmek oldukça zordur. Tartışmanın özellikle Nadîr ve Kurayza kabileleri özelinde devam ettiği unutulmamalıdır. Ayrıca Yahudi kabilelerinden bazılarının Araplarla evlenmesi ${ }^{94}$ ya da bazı Arap kabilelerinin Yahudiliği benimsemesi ${ }^{95}$ de işin izahını oldukça zorlaştırmaktadır.

Medine’ye yerleşen Yahudiler, şehrin savunması için kaleye benzeyen konaklar (utum) inşa etmişler; ${ }^{96}$ su kuyuları açarak ${ }^{97}$ sahip oldukları verimli arazileri işlemişler, ${ }^{98}$ değişik

87 İbn Sa'd, et-Tabakât, X, 123; Belâzürî, Ensâb, I, 444; İbn 'Abdülber, el-İstî̀ âb, IV, 1872. Bu konudaki görüşlerin değerlendirilmesi için bk. Arslantaş, Hz. Muhammed Döneminde Yahudiler, s. 90-91.

88 Burrû, Târîh, s. 186.

89 Cevâd Ali, el-Mufassal, XII, 98.

90 Welfenson, Târîhu'l-yehûd, s. 16.

91 Ya kûbî, Târîh, I, 122, 123; Mes' ûdî, et-Tenbîh, s. 213.

92 Hitti, İslam Tarihi, I, 96.

93 Arslantaş, Hz. Muhammed Döneminde Yahudiler, s. 95.

94 Ka 'b b. Eşref’in babası Tay kabilesinden, annesi ise Benî Nadîr kabilesindendi (bk. İbn İshâk, es-Sîre, s. 317; İbn Hişâm, es-Sîre, I, 514).

95 Hâris b. Kâ‘b, Gassân, Cüzâm, Belî, Evs ve Hazrec kabilelerinden bazı kimselerin Yahudiliği benimsediği rivayet edilmiştir (bk. Ya kûbî, Târîh, I, 101).

96 Semhûdî, Vefâ, I, 125.

97 el-Bekrî, Mu'cem, I, 43.

98 Medine, çevresinde tarla ve hurma bahçelerinin yer aldığı; dağınık yerleşimin bulunduğu bir kasaba görüntüsündeydi. Bu sebeple sayıları yaklaşık iki yüze ulaşan ve şehre saldırı olduğunda halkın içine sığındıkları savunma amaçlı kale ve utumlar inşa edilmişti. Utumların inşasında Yemen’deki mimariden istifade edilmiş olmalıdır (bk. Watt, "al-Madīna", $E I^{2}$, V, 994; Sâlim, Dirâsât, s. 341; ayrıca bk. Buhl, “Medine”, İ, VII, 460). 
meyve aşılama yöntemlerini kullanmışlar, ${ }^{99}$ özellikle hurma ve hububat üretiminin gelişmesinde aktif rol üstlenmişlerdir. ${ }^{100}$ Onlar daha önce yaşadıkları yerlerde ziraat alanlarında başarılı işler gerçekleştirdikleri ve bu konuda özel bir tecrübeye sahip oldukları için mesleki yeterliliklerini Yesrib’e taşımışlardır. ${ }^{101}$ Böylece şehrin hem iskânı hem de tarımsal faaliyetlerinin ilerlemesine katkı sağlamışlardır. ${ }^{102}$

Medine'de yaşayan Yahudilerden Kurayza ve Nadîr kabileleri ilk olarak şehrin alt kısmına yerleşmişti. Ancak bulundukları yerdeki iklim şartları onları rahatsız ettiği için yeni bir yer arayışına girdiler. Çevreyi keşfetmesi için gönderdikleri elçi, Buthân ve Mehzûr vadilerinde tatlı su kaynaklarının olduğunu haber verdi. Bunun üzerine Benî Kurayza ${ }^{103}$ ve Hedl kabilesi ${ }^{104}$ bölgenin en verimli arazilerinden şehrin güneydoğusundaki Mehzûr vadisine, Benî Nadîr ve beraberindekiler ise Buthân vadisine ${ }^{105}$ yerleşti. ${ }^{106}$ Benî Kurayza ve Nadîr mensupları geçimlerini tarım ve ticaretten sağlamaktaydı. Nitekim Nadîr kabilesinin ilk defa kuyular açtıkları rivayet edilmektedir. ${ }^{107}$

Benî Kaynukâ‘ kabilesi, Medine’nin güneybatısındaki Musallâ yakınında Vâdîbuthân üzerindeki köprünün yanına yerleşmişti. Cesaret ve savaşçıllğ̆ıla meşhur olan Benî Kaynukâ' mensupları, diğer Yahudi kabileleri gibi ne arazilere sahipti ne de tarım işleriyle ilgilenmekteydiler. ${ }^{108}$ Onlar geçimlerini ticaret, silah imalatı ve kuyumculukla sağlıyordu. ${ }^{109}$ Ayrıca Buthân köprüsünün yanında Sûk-u Benî Kaynukâ' adı verilen çarşısı ve iki kaleleri ${ }^{110}$ vardı. ${ }^{111}$ Benî Kaynukâ' mensuplarının diğer iki Yahudi kabilesine nazaran daha zengin olduğu bilinmektedir. ${ }^{112}$

Medine’nin diğer sakinleri, anavatanları Güney Arabistan olan Evs ve Hazrec kabileleridir. Kardeş olan bu kabilelerin Me'rib seddinin yıkılmasından sonra Medine ve civarına yerleștiği tahmin edilmektedir. Ancak bunun tarihini tam olarak tespit edebilmek mümkün değildir. Bunun en önemli nedenlerinden birisi de seddin tarihî süreç içinde çok defa yıkılması ve tamir görmesidir. Konuya eserlerinde yer veren İslâm kaynakları özellikle yıkılışın

99 Arslantaş, Hz. Muhammed Döneminde Yahudiler, s. 89.

100 el-Bekrî, Mu'cem, I, 43; Semhûdî, Vefâ, I, 130.

101 Welfenson, Târîhu'l-yehûd, s. 10.

102 Buhl, "Medine”, İA, VII, 460; Bozkurt-Küçükaşcı, "Medine”, DİA, XXVIII, 306.

103 Benî Kurayza diğer Yahudi kabileleri gibi İbrânîce yazıyor ve Arapça konuşuyordu. Ayrıca çocuklarına kendi isimlerinin yanında Arap isimleri de veriyordu (bk. Avc1, "Kurayza", DİA, XXVI, 431).

104 Benî Hedl’in Kurayza kabilesi ile yakın ilișkisi bulunmaktadır (bk. Semhûdî, Vefâ, I, 129).

105 Müzeynib olduğu da söylenmiştir (bk. el-Bekrî, el-Mesâlik, I, 414. Ayrıca Benî Nadîr mensuplarının el-Gars bölgesinde de evleri vardı (bk. İbn Sa 'd, et-Tabakât, II, 53; Mes' ûdî, et-Tenbîh, s. 213).

106 Ebü'l-Ferec el-İsfahânî, el-Egânî, XXII, 344; Yâkût, Mu'cem, V, 234.

107 Semhûdî, Vefâ, I, 129.

108 eş-Şerîf, Mekke ve'l-Medine, s. 267.

109 Belâzürî, Ensâb, I, 266.

110 Semhûdî, Vefâ, IV, 53.

111 Beyhakî, Delâ' il, III, 173.

112 Avcl, "Kaynukāe”, DİA, XXV, 88. 
sebepleri ve zamanı üzerinde durmuşlardır. ${ }^{113}$ Bu konuda kaynakların genel kanaati, bölgede yaşayan Ezd ${ }^{114}$ ve Gassân kabilelerinin seddin yıkılmasından sonra topraklarının verimsiz hale geleceğini düşündükleri için Kuzey Arabistan’a göç ettikleri şeklindedir. ${ }^{115}$ Hatta Mes 'ûdî, Gassân kabilesinin bu olayı “âmü’s-seyl” olarak adlandırarak takvim başlangıcı kabul ettiğini ifade etmiştir. ${ }^{116}$ Ancak bu bilgi doğru kabul edildiği takdirde seddin yık1lış tarihi, biraz daha öne alınmış olur (M.Ö. III-I. yüzyıl). Bu da seddin sonraki dönemlerde yıkıldığını belgeleyen kitâbelere (M.S. 542) ters düşmektedir. Nitekim Güney Arabistan harabeleri üzerinde özel çalışmaları bulunan Avusturyalı kâşif Eduard Glaser’in bu konudaki tercihi önemlidir. O, kitâbelerden de istifade ederek seddin en erken 542 yılında yıkılmış olabileceğini söylemiştir. Dolayısıyla Me'rib Seddi’nin muhtemelen 542-570 yılları arasındaki bir tarihte yıkıldığını söylemek daha isabetlidir. Bu bakımdan Kur'ân'da belirtilen sel ve barajın son yıkılışına sebep olan su baskını, bu tarihlere de uygun düşer. Ancak bu durumda Kur'ân'da belirtilen "seylü’l- 'arim” in ${ }^{117}$, göçlerin sebebi olarak gösterilmesi doğru olmamalıdır. Çünkü göçler, son baskından en az iki yüzyıl önce gerçekleşmiştir. Bu farklılık, sel baskınlarının muhtelif zamanlarda tekrarlanmış olmasıyla da izah edilebilir. ${ }^{118}$

Me’rib seddi’nin yıkılışı etrafında devam eden tartışmalar Evs ve Hazrec kabilelerinin şehre gelişleriyle doğrudan bağlantılı olduğu için bu konuda varılacak sonuçlar oldukça önemlidir. Ahmed İbrahim eş-Şerîf, Hazrec kabilesine mensup Sa 'd b. Ubâde’nin nesebinden ${ }^{119}$ hareketle onların miladî IV. asra doğru Yesrib’e gelmeye başladığını söylemiştir. eşŞerîf'e göre Sa 'd b. Ubâde ile kabileye adını veren Hazrec b. Hârise arasında on bir nesil vardır. Her bir kuşak arasında da yaklaşık yirmi beş yıl olabileceğinden Hazrec b. Hârise ile Sa 'd b. Ubâde arasında 275 yıllık bir zaman dilimi ortaya çıkar. Dolayısıyla Hz. Peygamber'in Medine’ye geliş tarihi olan 622 yılından 275 yılı çıkartıldığında 347 tarihi bulunmaktadır. Bu ise

113 Me'rib Seddi'nin yıkılması hakkında kaynaklarda farklı rivayetler vardır. Bazıları tarih vermeksizin seddin Ezd kabilesinden 'Amr b. 'Âmir'in veya kardeşi İmrân’n hükümdarlı̆̆ı zamanında yıkıldığını (İbn Hişâm, es-Sîre, I, 1314; Mes 'ûdî, et-Tenbîh, II, 167); Hamza el-İsfahânî, seddin yıkılışının İslâm’dan dört asır önce olduğunu (Târîh, s. 90), Yâkût ise Yemen'deki Habeş hâkimiyeti zamanında gerçekleştiğini söylemişlerdir ( Mu'cem, V, 35; Makrîzî, Imtâ' u'lesmâ', IX, 171). Bazı araştırmacılar da yeni tarihler belirtmiştir. Onlardan bir kısmı yıkılışın milattan önceki bir zamanda olduğunu, bazıları da milâttan sonra 170 ve 210'lu yıllarda vuku bulduğunu ileri sürmüştür (bk. Kelpetin, İslâm Öncesi Güney ve Kuzey Arabistan, s. 46).

114 İlk zamanlarda Yemen'de yaşayan Ezdliler, Me'rib Seddi’nin yıkılmasından sonra çeşitli yerlere dağıldılar. Bunlardan Evs ve Hazrec kolu Yesrib’e göç etti (bk. Algül, "Ezd”, DİA, XII, 46).

115 Belâzürî, Fütûh, s. 25; Ya kûbî, Târîh, I, 79; İbnü'l-Verdî, Târîh, I, 61.

116 Mes' ûdî, et-Tenbîh, s. 173.

117 "And olsun, Sebe halkı için kendi yurtlarında bir ibret vardı: Biri sağda, biri solda iki bahçe bulunuyordu. Onlara şöyle denilmişti: "Rabbinizin rızkından yiyin ve O’na şükredin. Beldeniz güzel bir belde, Rabbiniz de çok bağışlayıcı bir Rabdir." Fakat onlar yüz çevirdiler. Biz de onlara 'Arim selini gönderdik. Onların bahçelerini ekşi meyveli ağaçlar, acı ılgın ve biraz da sedir ağacı bulunan iki bahçeye çevirdik. Nimetlere karşı nankörlük etmeleri sebebiyle onları işte böyle cezalandırdık. Biz (bu şekilde) ancak nankörleri cezalandırırı"' (Sebe' 34/15-17).

118 Harman, "Arim”, DİA, III, 374.

119 Sa ' d b. 'Ubâde b. Düleym b. Hârise b. Ebû Huzeyme b. Sa lebe b. Tarîf b. Hazrec b. Sâ ide b. Ka b b. Hazrec b. Hârise (bk. Halîfe b. Hayyât, et-Tabakât, s. 166). 
Evs ve Hazrec'in Yesrib’e yerleşmesine denk gelmektedir. ${ }^{120}$ eş-Şerîf'in yaş ve neseb esaslarına dayalı bu iddiasını mutlak bir bilgi olarak değerlendirmemek gerekir. ${ }^{121}$ Bununla birlikte Güney Arabistan'dan Yesrib’e göçün başlangıcına ilişkin önemli bilgiler ihtiva etmesi, Evs ve Hazrec kabilelerinin şehre yerleşmesi hakkında yaklaşık bir tarih vermesi bakımından önemlidir. Ayrıca Güney Arabistan'dan diğer bölgelere yapılan göçü, tek başına Me'rib Seddi’nin yıkılması ile ilişkilendirmek de doğru değildir. Bölgedeki siyasî istikrarın bozulması, onun neden olduğu Hıristiyan-Yahudi çatışması, ticaret güzergâhının değişmesi, Habeş ve Sâsânîler'in siyasete müdahalesi gibi hususlarla da yakından ilgilidir. ${ }^{122}$

Evs ve Hazrec kabileleri Yesrib’e ilk geldiklerinde şehrin ekonomik ve siyasî gücü Yahudilerin kontrolündeydi. Bununla birlikte Yahudiler, onların Yemen'deki ziraat ve ticaret tecrübesinden istifade etmek istedikleri için şehre yerleşmelerine izin vermişti. Ancak Evs ve Hazrec kabileleri siyasî ve ekonomik açıdan bağımsızlığını kazanmadığı için Yahudilere tabi olarak ${ }^{123}$ varlıklarını devam ettirmişlerdi. Onlar yeni yerleştikleri bu şehirde siyasî varlıklarını koruyabilmek ve ekonomik açıdan rahata kavuşabilmek için Yahudilerin desteklerine ihtiyaç duymaktaydılar. Nitekim uzun bir süre onların ziraî işlerini görmüşlerdi. Evs ve Hazrec mensupları bir süre sonra güçlenmeye ve ekonomik açıdan rahata ulaşmaya başlayınca da Kaynukâ' ve Nadîr kabileleri şehirde elde ettikleri imtiyazları kaybedeceklerini düşündüler. Bunun üzerine Arap kabileleri ile yaptıkları anlaşmayı bozdular ve onlara karşı her türlü baskıyı uygulamaya başladılar. ${ }^{124}$ Hatta Arap kabileleri bazan onur kırıcı davranışlara da maruz kalmışlardı: Rivayete göre Benî Sa lebe kabilesine mensup ${ }^{125}$ Yahudi "kralı" Fityevn, şehirde Evs ve Hazrec kabilelerinden evlenecek kızların ilk geceyi kendi yanında geçirmelerini şart koşmuştu. Bu kabileler, kararı beğenmeseler de korktukları için buna bir süre boyun eğdiler. Buna tahammül edemeyen Hazrec kabilesinin liderlerinden Mâlik b. Aclân, kız kardeşinin düğün gecesinde gelinle birlikte kadın kılığına büründü ve Fityevn'in konağına girdikten sonra onu öldürdü. ${ }^{126}$ Arkasından ailesini de yanına alarak Ebû Cübeyle olarak

120 eş-Şerîf, Mekke ve'l-Medine, s. 260.

121 Louis Amélie Sédillot, göçün 300 yılında gerçekleştiğini söyler. bk. Târîhu'l-Arabi'l- 'âm, s. 51.

122 Mehrân, Dirâsat, s. 409.

123 Evs ve Hazrec kabileleri ekonomik ve siyasî açıdan giderek güçlenmeye başlayınca Yahudi kabileleriyle civâr (Câhiliye devrinde ve İslâm’ın ilk dönemlerinde son derece yaygın olan eman ve himaye müessesesini ifade etmektedir [Önkal, "Civâr", DİA, VIII, 34]) ve hilf (Câhiliye döneminde kabilelerin veya şahısların yardımlaşma, dayanışma ve himaye amacıyla yaptıkları antlaşma ve ittifakları ifade etmektedir. Hilf yapan kimselere de halîf denilmektedir [Özkuyumcu, "Hilf", DIA, XVIII, 29]) adı verilen ittifaklar kurmuşlardı (bk. Semhûdî, Vefâ, I, 142; Cevâd Ali, el-Mufassal, VII, 129).

124 Semhûdî, Vefâ, I, 142.

125 İbn Hişâm, es-Sîre, I, 514.

126 Rivayetin sıhhati konusunda bazı eleştiriler getirilmiştir. Bunlar özetle şöyle sıralanabilir: 1) Câhiliye dönemindeki Arap kabilelerinin hayatı hakkında bilgilerin azlı̆̆ına, Evs ve Hazrec kabilelerinin İslâm öncesi Yesrib’deki durumlarıyla ilgili bilgilerin sınırlı olmasına rağmen rivayette çok fazla ayrıntının bulunması. 2) İlahi dinlerden biri olan Yahudilikte ahlaksızlık kötülenmekle birlikte burada buna aykırı işlere yer verilmesi. 3) Medine'de yaşayan Yahudilerde "krallık" sisteminin varlığıyla ilgili kaynaklarda herhangi bir bilginin olmaması. 4) Kaynaklarda Fityevn isminde Yahudi kralı bulunmamaktadır. Ayrıca Fityevn'in kökeninin Arap ya da Yahudi olmasıyla ilgili kaynaklarda farklı bilgiler yer alır. 4) Bazı kaynaklarda (İbnü’l-Kelbî, Neseb, I, 419; İbn Düreyd, el-Isstikâk, s. 461; İbn Hazm, Cemhere, s. 356.) Ebû Cübeyle, Gassânî emiri olarak zikredilmesine rağmen bu doğru değildir. Gassânîler arasında bu 
bilinen Gassânî ileri gelenlerinden birinin yanına sığındı. Yahudiler’in bu uygulamasından rahatsızlık duyan Gassânîler, onlarla savaştı ve Yahudilerden pek çok kimseyi öldürdü. ${ }^{127} \mathrm{Bu}$ gelişme üzerine Evs ve Hazrec kabileleri maruz kaldıkları baskı ve zulümden kurtuldu (492). Onlara karşı üstünlüklerini kaybeden Yahudilerden, Benî Kurayza ve Nadîr, Evsliler ile; Benî Kaynukâ' ise Hazrecliler ile anlaşarak yaşamlarını sürdürmeye çalıştılar. ${ }^{128}$ Böylece şehrin idaresi Evs ve Hazrec kabilelerinin kontrolüne geçti. ${ }^{129}$

Evs ve Hazrec kabilelerinin liderliğinde Medine'de oluşan bu yeni durum, çok uzun sürmedi. Yahudilerin kışkırtmalarından sonra bu iki Arap kabilesi, kısa süre sonra birbirlerine düştü. Onların yaklaşık 120 yıl boyunca birbirleriyle savaştıkları ve iki kabile arasında bu kadar uzun süren başka bir çarpışmanın bilinmediği söylenir. ${ }^{130}$ Onlar arasındaki ilk mücadele, Sümeyr savaşıdır. Rivayete göre Evs kabilesinden Sümeyr isimli bir kimse Hazrec kabilesinden Mâlik b. Aclân’ın himâyesine giren ve onun halîfi olan Ka'b b. Aclân’ı öldürdü. Bunun üzerine Mâlik de Ka'b’’n kâtilinin teslim edilmesini istedi. Ancak onlar katilin bilinmediğini söylediler ve talebi geri çevirdiler. Ardından maktulün diyetini ödemeye karar verdiler. İki taraf arasındaki anlaşma hükümlerine göre halîf olana hür şahsa göre yarı diyet ödenmekteydi. Ancak Mâlik bunu kabul etmedi. Böylece taraflar arasında savaş kaçınılmaz oldu. Mücadele sonunda Evs kabilesi, Hazrec’e üstünlük sağladı. Ancak bu savaş, sorunu çözmediği gibi iki kardeş kabile arasında uzun yıllar devam edecek olan kin ve nefret tohumlarının ekilmesine sebep oldu ve yeni savaşlara yol açtı. İki taraf arasında yıllar içinde cereyan eden belli başlı savaşlar şunlardır: Kâ' 'b b. Amr, Serâre, Dîk, ${ }^{131}$ Mu abbis, Mudarris, Hâtıb, Fâri' ${ }^{\prime}$ Birinci Ficâr, İkinci Ficâr, Rubey' ve Buâs. ${ }^{132}$ Bunların içinde en şiddetli olan Buâs harbi olmuştur. ${ }^{133}$ Buâs harbi Medine’nin güneydoğusunda Benî Kurazyâ topraklarındaki bir vahada gerçekleşmiştir. Kaynaklarda "Yevmü Buâs" diye zikredilen bu savaş, Evs kabilesinden bir kimsenin Hazrec'e sığınan bir yabancıyı öldürmesi üzerine başlamıştır. Buâs savaşında Evs kabilesinin liderliğini Hudayr el-Ketâib, Hazrec'in kumandanlığını ise Amr b. Nu 'mân el-Beyâzî üstlenmişti. İki tarafın da ağır kayıplar verdiği mücadele sonunda başta

isimle bilinen bir yönetici yoktur (bk. İbnü’l-Esîr, el-Kâmil, I, 585. 5). Yine Mâlik b. Aclân’n Yahudilerden korunmak için sığındığı söylenen kimsenin ismi, bazan Gassâni emiri Ebû Cübeyle olarak bazen de Yemenli Tübba a b. Hassân ve Es 'ad Ebû Kerib şeklinde rivayet edilmesi. 6) Rivayetin muhteva itibariyle tıpkı Yemâme bölgesinde yaşayan Cedîs ile Tasm kabileleri arasında efsânevî bir mahiyet ihtiva eden nakillere benzemesi (geniş bilgi için bk. Mehrân, Dirâsat, s. 419-423).

127 Mâlik b. 'Aclân, bu olaydan dolayı Yahudilerin büyük lanet ve nefretini kazanmıştır. Yahudilerin ona karşı besledikleri kinin bir ifadesi olarak Mâlik'in resmini ibadethanelerine astıkları ve her fırsatta Mâlik'e lânet ettikleri rivayet edilir (bk. İbn Haldûn, el-'İber, II, 344; Cevâd Ali, el-Mufassal, VII, 134).

128 Cevâd Ali, el-Mufassal, XII, 109.

129 Yâkût, Mu'cem, V, 85; İbnü’l-Esîr, el-Kâmil, I, 584-585; Semhûdî, Vefâ, I, 142-145; Cevâd Ali, el-Mufassal, VII, 133135; Ahmet Önkal, "Hazrec”, DİA, XVII, 143.

130 Semhûdî, Vefâ, I, 170.

131 Semhûdî, Vefâ, I, 170.

132 Ya'kûbî, Târîh, I, 118 İbnü'l-Esîr, el-Kâmil, I, 587-601.

133 Benî Nadîr ve Benî Kurayza kabileleri Evs'e destek olmuş ve Benî Kaynukâ 'nın yardım ettiği Hazrec kabilesinin yenilgiye uğratılmasında rol oynamıștı (bk. Özkuyumcu, "Nadîr", DİA, XXXII, 275). 
Hazrec kabilesinin lideri 'Amr olmak üzere pek çok kimse öldü (617). ${ }^{134}$ Buâs savaşının Evs ve Hazrec kabileleri arasındaki en kanlı savaşlardan biri olmasına rağmen Medine’de İslâm’n yayılmasında ve müslümanların hicretinde çok önemli bir yeri vardır. Çünkü bu savaş sonunda Hazrec kabilesinden altı kişilik bir grup Mekkeliler'in desteğini alabilmek ve onlarla anlaşma yapabilmek için şehre geldi. Ancak Ebû Cehil'in Hazrecliler'in bu talebini geri çevirmesi üzerine onlar da nübüvvetin on birinci yllında Hz. Peygamber ile Akabe'de görüşerek müslüman oldular. ${ }^{135}$ Daha sonra bu altı kişi, Medineye döndüler ve kabilelerinin İslâmiyet'i kabulüne vesile oldular. Onlar girdikleri bu yeni din sayesinde iki kardeş kabile arasında düşmanlığın sona erebileceğini düşünmekteydiler. ${ }^{136}$ Nitekim Hz. Âişe’nin, "Buâs, Allah’in Allah Resûlü için hazırlamış olduğu bir gündü” hadisi ${ }^{137}$ bunu teyit etmektedir.

134 İbn Hișâm, es-Sîre, I, 555-556; İbnü'l-Esîr, el-Kâmil, I, 601-602; İbn Haldûn, el- 'İber, II, 346; Makrîzî, İmtâ' u'l-esmâ', IX, 187; Çubukçu, "Buâs”, DİA, VI, 340.

135 Ya kûbî, Târîh, I, 118; Semhûdî, Vefâ, I, 170.

136 Önkal, "Hazrec", DİA, XVII, 144.

137 Ahmed b. Hanbel, el-Müsned, XL, 376. 


\section{Kaynaklar}

Ahmed b. Hanbel, Ebû Abdullah, el-Müsned (nşr. Şu 'ayb el-Arnaût-v.dğr.), I-L, Beyrut 1416-1421/19952001.

Algül, Hüseyin, “Ezd”, DİA, XII, 46-47.

Apaydın, Mehmet, “Siyer Coğrafyası’nın İklimi, Bitki Örtüsü ve Hayvanları”, 2014-2015 Ders Yılı Siyer Mektebi Müfredatı Hz. Peygamber (sas) Dönemi Siyer Coğrafyası, İstanbul 2014.

Arslantaş, Nuh, Hz. Muhammed Döneminde Yahudiler, İstanbul 2016.

Avc1, Casim, "Kaynukā'”, DIA, XXV, 88.

-----, "Kurayza", DİA, XXVI, 431.

el-Belâzürî, Ahmed b. Yahya, Ensâbü’l-Eşrâf(nşr. Süheyl Zekkâr, Riyâd ez-Ziriklî), I-XIII, Beyrut 1417/1996.

------, Fütûhu'l-büldân, Beyrut 1988.

el-Beyhakî, Ahmed b. Hüseyin, Delâ’ ilü’n-nübüvve (nşr. Abdülmu 'tî Kal' acî), I-VII, Beyrut 1408/1988.

Bozkurt, Nebi-Küçükaşc1, Mustafa Sabri, “Medine”, DİA, XXVIII, 305-311.

Buhl, Fr., "Medine", İslâm Ansiklopedisi (İA), VII, 459-471.

Burrû, Tevfîk, Târîhu'l-'Arabi'l-kadîm, Beyrut 1422/2001.

Cevâd Ali, el-Mufassal fî târîhi'l-'Arab kable'l-İslâm, I-XX, Beyrut 1422/2001.

Çubukçu, Asri, "Buâs”, DİA, VI, 340.

ed-Diyârbekrî, Kâdî Hüseyin b. Muhammed, Târîhu’l-hamîs fî ahvâli enfesi nefis, I-II, Beyrut ts.

Ebû Ubeyd el-Bekrî, Abdullah b. Abdülazîz, el-Mesâlik ve’l-memâlik (nşr. A. P. van Leeuwen ve A. Ferre), I-II, Tunus 1992.

-----, Mu cem me’sta'cem min esmâi' l-bilâd ve'l-mevâdı (nşr. Mustafâ es-Sakkâ), I-IV, Beyrut ts.

Ebü'l-Ferec el-İsfahânî, Ali b. el-Hüseyin b. Muhammed, el-Egânî, I-XXV, Beyrut 1415/1995.

Erdem, Sargon, "Amâlika", DİA, II, 556-557.

Gadbân, Yâsin, Medînetü Yesrib kable’l-İslâm, Amman 1993.

Gil, Moshe, "The Origin of the Jews of Yathrib", Jerusalem Studies in Arabic and Islam, 4 (1984), s. 205-209.

Güç, Ahmet, "Yahudilik", DİA, XLIII, 207-212.

Günaltay, M. Şemsettin, İslâm Öncesi Arap Tarihi (haz. M. Mahfuz Söylemez), Ankara 2013.

Halîfe b. Hayyât, Kitabü’t-tabakât (nşr. Süheyl Zekkâr), Beyrut 1414/1993.

Halîl b. Ahmed el-Ferâhidî, Ebû Abdurrahman, Kitâbü’l- Ayn (nşr. Mehdî Mahzûmî-İbrahim es-Sâmerrâî), I-VIII, Beyrut 1408/1988.

Ḥamza el-İsfahânî, Ebû Abdillâh, Târîhu sinî mülûki’l-ard ve’l-enbiyâ’', Beyrut 1961.

Harman, Ömer Faruk, “Arim”, DİA, III, 374.

------, "Buhtunnasr", DİA, VI, 380-381.

------, "Hârûn”, DİA, XVI, 255.

-----, "Kudüs”, DİA, XXVI, 325.

Hitti, Philip K., Siyâsî ve Kültürel İslam Tarihi (trc. Salih Tuğ), I-II, İstanbul 1995.

İbn Abdülber, Ebû Ömer, el-İstî‘ âb fî ma'rifeti'l-'Ashâb (nşr. Ali Muhammed el-Bicâvî), I-IV, Beyrut $1413 / 1992$.

İbn Asâkir, Ebü'l-Kâsım, Târîhu medîneti Dımaşk (nşr. Ömer b. Garâme el- 'Amrî), I-LXXX, Beyrut 14151421/1995-2001.

İbn Düreyd, Ebû Bekir Muhammed b. el-Hasan, el-I̦ştikâk (nşr. Abdüsselâm Muhammed Hârûn), Beyrut $1411 / 1991$. 
İbn Habîb, Ebû Ca fer Muhammed, el-Muhabber (nşr. Ilse Lichtenstädter), Beyrut ts.

İbn Haldûn, Ebû Zeyd Veliyyüddîn, Kitâbü'l- İber (nşr. Halîl Şehhâde-Süheyl Zekkâr), I-VIII, Beyrut 14011403/1981-1983.

İbn Hazm, Ebû Muhammed Ali b. Ahmed, Cemheretü ensâbi'l-'Arab, Beyrut 1403/1983.

İbn Hibbân, Ebû Hâtim Muhammed el-Büstî, es-Sikât (nşr. Muhammed Abdürreşîd), I-IX, Haydarâbâd 1393-1403/1973-1983.

İbn Hişâm, Ebû Muhammed Cemâlüddîn Abdülmelik, es-Sîretün-nebeviyye (nşr. Mustafa es-Sekkâ v.dğr.), I-II, Misir 1375/1955.

İbn İshâk, Muhammed, Kitâbü'l-Megâzî (Sîretü İbn İshâk, el-Mübtede' ve'l-meb'as ve'l-megâzî) (nşr. Muhammed Hamîdullah), Konya 1401/1981.

İbn Kesîr, Ebü'l-Fidâ, el-Bidâye ve’n-nihâye (nşr. Abdullah b. Abdülmuhsin et-Türkî), I-XXI, Cize 14171420/1997-1999.

İbn Kuteybe, Abdullah b. Müslim, el-Ma' ârif (nşr. Servet 'Ukkâşe), Kahire 1413/1992.

İbn Rüste, Ebû Ali Ahmed b. Ömer, el-A 'lâku’n-nefîse (nşr. M. J. de Goeje), Leiden 1892.

İbn Sađd, Ebû Abdullah Muhammed, et-Tabakâtü'l-kübrâ (nşr. Ali Muhammed Ömer), I-X, Kahire $1421 / 2001$.

İbn Şebbe, Ebû Zeyd Ömer, Târîhu'l-Medînetil'-münevvere (nşr. Fehîm M. Şeltût), I-IV, Cidde 1399/1979.

İbnü'l-Cevzî, Ebü'l-Ferec, el-Muntazam fî târîhi'l-mülûk ve'l-ümem (nşr. Muhammed Abdülkâdir AtâMustafa Abdülkâdir Atâ), I-XIX, Beyrut 1412/1992.

İbnü'l-Esîr, Ebü'l-Hasan İzzüddîn, el-Kâmil fî̀t-târîh (nşr. Ömer Abdüsselâm Tedmürî), I-X, Beyrut $1417 / 1997$.

İbnü'l-Kelbî, Hişâm b. Muhammed, Nesebü Me'ad ve'l-Yemeni'l-kebîr (nşr. Nâcî Hasan), I-II, Beyrut $1408 / 1988$.

İbnü’l-Verdî, Ebû Hafs Zeynüddîn, Târîhu İbni'l-Verdî, I-II, Beyrut 1417/1996.

Kelpetin, Mahmut, İslâm Öncesi Güney ve Kuzey Arabistan, İstanbul 2016.

Küçükaşç1, Mustafa Sabri, “Harre”, DİA, XVI, 244-245.

el-Makrîzî, Ebû Muhammed, İmtấu'l-esmâ (nşr. Muhammed Abdülhamîd en-Nümeysî), I-XV, Beyrut $1420 / 1999$.

Mehrân, Muhammed Beyyûmî, Dirâsât fî târîhi'l- 'Arabi'l-kadîm, Riyad 1400/1980.

el-Mes 'ûdî, Hüseyin b. Ali, et-Tenbîh ve’l-İşrâf (nşr. Abdullah es-Sâvî), Kahire 1357/1938.

Önkal, Ahmet, "Civâr", DİA, VIII, 34.

-----, "Hazrec", DIA, XVII, 143-144.

Özkuyumcu, Nadir, “Hilf”, DİA, XVIII, 29.

-----, "Nadîr”, DİA, XXXII, 275.

al-Rashıd, Saad Abdul Azız, "Medina", The Oxford Encyclopedia of Archaeology in the Near East, III, 459.

Sâlim, Seyyid Abdülazîz, Dirâsât fî târîhi'l- 'Arab kable'l-İslâm, İskenderiye ts.

Sédillot, Louis Amélie, Târîhu'l-Arabi'l-'âm (trc. 'Âdil Zuaytir), Kahire 1948.

es-Semhûdî, Ahmed b. Ali el-Hasenî, Vefầ ü’l-vefâ bi-ahbâri dâri'l-Mustafâ (nşr. Hâlid Abdülganî Mahfûz), I-IV, Beyrut 1427/2006.

es-Süheylî, Ebü'l-Kâsım Abdurrahman b. Abdullah, er-Ravdu'l-ünüf fî̀ şerhi's-Sîreti’n-nebevîyye (nşr. 'Abdurrahman el-Vekîl), I-VII, Kahire 1410/1990.

eş-Şerîf, Ahmed İbrahim, Mekke ve'l-Medine fi'l-câhiliyye ve ahdirr-resûl sallahu aleyhi ve sellem, Kahire ts. 
et-Taberî, Ebû Ca'fer Muhammed b. Cerîr, Târîhu'l-ümem ve'l-mülûk (nşr. Muhammed Ebü’l-Fazl İbrahim), I-XI, Beyrut 1387/1967.

el-Vâkıdî, Ebû Abdullah Muhammed b. Ömer, el-Megâzî̀ (nşr. Marsden Jones), I-III, Beyrût 1409/1989. Watt, W. M., "al-Madīna”, $E I^{2}$, V, 994-995.

Welfenson, Israil, Târîhhu'l-yehûd fî bilâdi'l-Arab fi'l-câhiliyye ve sadri'l-İslâm, Misır 1927.

el-Ya kûbî, Ahmed b. Ebû Ya'kûb b. Vâdıh, Târîhu’l-Ya'kûbî, I-II, Beyrut ts.

Yâkût el-Hamevî, Ebû Abdullah Şihâbüddîn, Mu'cemüll-büldân, I-V, Beyrut 1397/1977.

Yazır, Elmalılı Muhammed Hamdi, Hak Dini Kurân Dili: Türkçe Tefsir, I-X, İstanbul 1979.

ftp://ftp.atdd.noaa.gov/pub/GCOS/WMO-Normals/RA-II/SD/40430.TXT (erişim tarihi: 05.06.2017). 
